\title{
Endoscopic features of intestinal follicular lymphoma: the value of double-balloon enteroscopy
}

Intestinal follicular lymphoma is uncommon, and its endoscopic appearance has seldom been described [ $1-4]$. We report five patients with primary intestinal follicular lymphoma in whom the whole of the gastrointestinal tract were examined using esophagogastroduodenoscopy (EGD), colonoscopy, and double-balloon enteroscopy [5].

The clinical and endoscopic features of the five patients are summarized in Table 1. All the patients underwent EGD, colonoscopy, and double-balloon enteroscopy via antegrade and retrograde approaches (Fujinon-Toshiba ES Systems Co., Tokyo, Japan). Four patients (80\%) had lesions in multiple sites in the gastrointestinal tract. The most frequent site was the jejunum, followed by the duodenum and the ileum. In three patients, EGD revealed multiple small, whitish nodules in duodenum, predominantly around the ampulla of Vater. On colonoscopy, one pa-

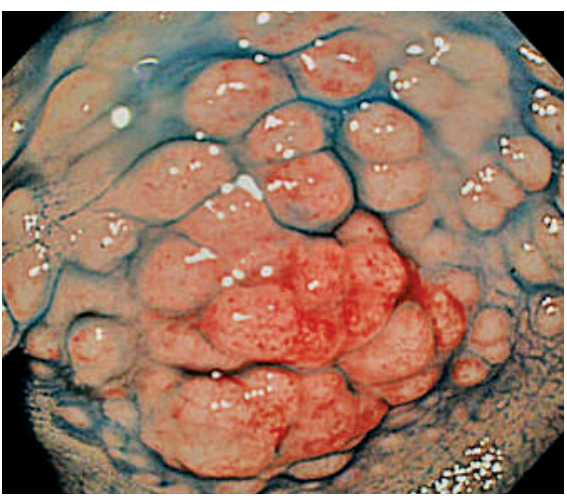

Figure 1 Colonoscopic view showing a superficially elevated lesion composed of aggregates of small nodules in the rectum in patient 3.

elevated lesion with aggregates of small nodules in the rectum (Figure $\mathbf{1}$ ), in addition to the ileal lesions. Interestingly, this Helicobacter pylori-negative patient showed regression of both rectal and ileal lesions on follow-up colonoscopy 15 months after antibiotic treatment.
Double-balloon enteroscopy revealed multiple polypoid lesions resembling lymphomatous polyposis in long segments of the jejunum or ileum in four patients (80\%) (Figure $\mathbf{2}$ a, b). The remaining patient also showed lymphomatous polyposis-like lesions in the ileum, but multiple biopsies failed to reveal lymphoma cells. Swollen Kerckring folds with mass formation was observed in three patients, and severe jejunal stenosis in two (Figure $\mathbf{2} \mathbf{c}, \mathbf{d}$ ). In all the patients, a histologic diagnosis of grade 1 follicular lymphoma was made by endoscopic biopsy, with infiltration of neoplastic cells positive for CD20, CD79a, CD10, and BCL2 but negative for CD3, CD5, and cyclin D1.

A variety of endoscopic features of intestinal follicular lymphoma were observed. Lymphomatous polyposis is considered to be one of the most characteristic findings, and this can often be detected using double-balloon enteroscopy. Double-balloon enteroscopy is a valuable tool for

Table 1 Clinical and endoscopic features of five patients with primary intestinal follicular lymphoma

\begin{tabular}{|c|c|c|c|c|c|c|c|c|c|c|}
\hline Patient & $\begin{array}{l}\text { Age/ } \\
\text { Sex }\end{array}$ & Symptoms & Stage & $\begin{array}{l}\text { Sites } \\
\text { involved }\end{array}$ & EGD findings & $\begin{array}{l}\text { Colonoscopic } \\
\text { findings }\end{array}$ & DBE findings & Treatment & $\begin{array}{l}\text { Response to } \\
\text { treatment }\end{array}$ & Clinical outcome \\
\hline 1 & $55 / M$ & None & 1 & D & $\begin{array}{l}\text { Multiple small } \\
\text { nodules (D) }\end{array}$ & Normal & LP-like* (I) & Antibiotics $\dagger$ & Not evaluated & $\begin{array}{l}\text { Alive with disease, } \\
3 \text { months }\end{array}$ \\
\hline 2 & $58 / \mathrm{M}$ & $\begin{array}{l}\text { Abdominal } \\
\text { pain, emesis }\end{array}$ & $\mathrm{II}_{2}$ & J, I** & Normal & Normal & $\begin{array}{l}\text { Stenosis, mass, } \\
\text { fold swelling, } \\
\text { LP (J) }\end{array}$ & $\begin{array}{l}\text { Surgery plus } \\
\text { R-CHOP }\end{array}$ & $\begin{array}{l}\text { Complete } \\
\text { remission }\end{array}$ & $\begin{array}{l}\text { Alive without dis- } \\
\text { ease, } 12 \text { months }\end{array}$ \\
\hline 4 & $64 / M$ & None & $\mathrm{II}_{1}$ & $\mathrm{D}, \mathrm{J}$ & $\begin{array}{l}\text { Multiple small } \\
\text { nodules (D) }\end{array}$ & Normal & $\begin{array}{l}\text { Mass, fold } \\
\text { swelling, LP (J) }\end{array}$ & $\mathrm{R}-\mathrm{CHOP}$ & Partial remission & $\begin{array}{l}\text { Alive with disease, } \\
10 \text { months }\end{array}$ \\
\hline 5 & $71 / M$ & $\begin{array}{l}\text { Abdominal } \\
\text { pain, nausea }\end{array}$ & IV & $\mathrm{D}, \mathrm{J}$ & $\begin{array}{l}\text { Multiple small } \\
\text { nodules (D) }\end{array}$ & Normal & $\begin{array}{l}\text { Stenosis, mass, } \\
\text { fold swelling, } \\
\text { LP (I) }\end{array}$ & $\mathrm{R}-\mathrm{CHOP}$ & Partial remission & $\begin{array}{l}\text { Alive with disease, } \\
6 \text { months }\end{array}$ \\
\hline
\end{tabular}

EGD, esophagogastroduodenoscopy; DBE, double-balloon enteroscopy; LP, lymphomatous polyposis; R-CHOP, rituximab plus cyclophosphamide, doxorubicin, vincristine, and prednisolone.

$D$, duodenum; I, ileum; J, jejunum; $R$, rectum.

* Numerous small polypoid lesions were observed but biopsies failed to reveal lymphoma cells.

** Detected by intraoperative enteroscopy.

$\dagger$ Lansoprazole plus amoxicillin and clarithromycin for 7 days.

$\ddagger$ Rabeprazole plus amoxicillin, clarithromycin, and metronidazole for 14 days 

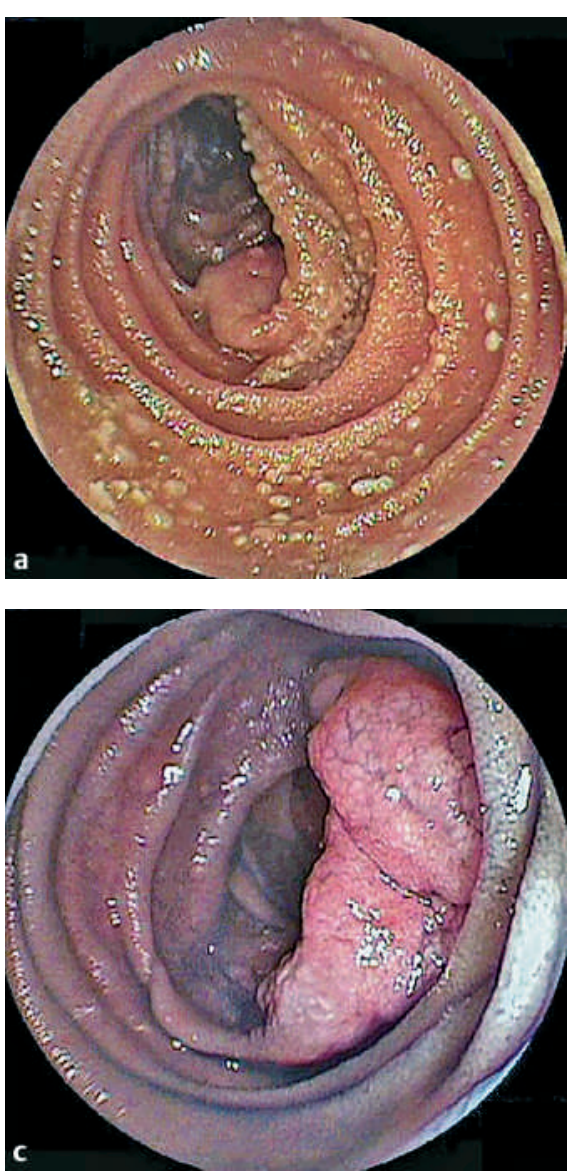

Figure 2 Double-balloon enteroscopic views of the jejunum in patients with intestinal follicular lymphoma. Numerous polypoid lesions of varying sizes, resembling lymphomatous polyposis, were seen, illustrated by images

the detection and accurate diagnosis of the small-intestinal lesions of this disease.

\section{Acknowledgment}

The authors are grateful for the help kindly provided by Professor Morishige Takeshita (Fukuoka University, Japan).

Endoscopy_UCTN_Code_CCL_1AC_2AC
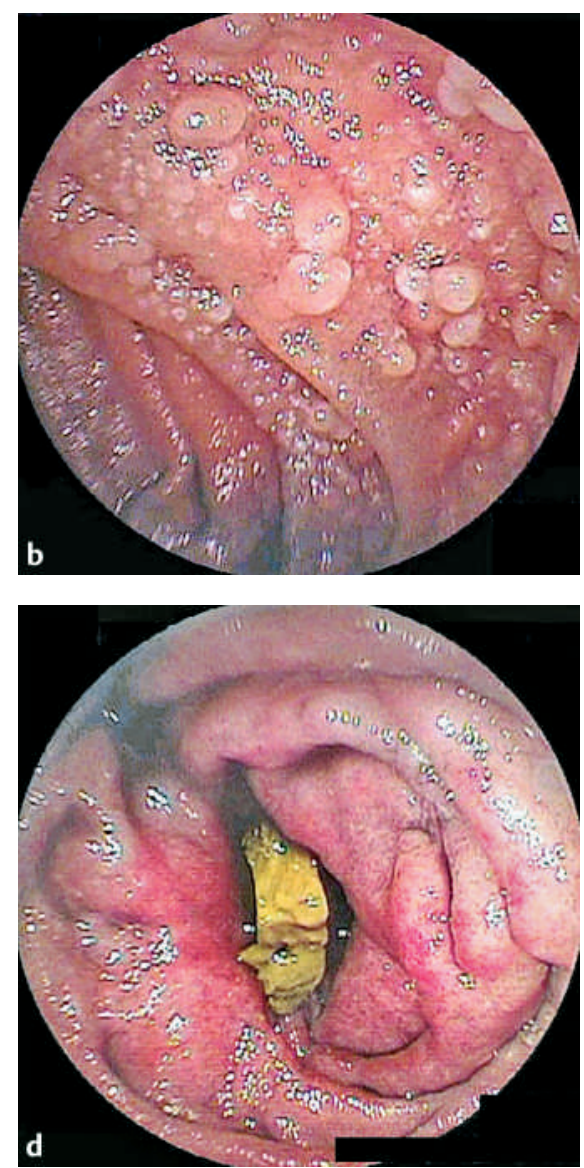

from patient 4 (a) and patient 5 (b). Patient 5 also showed mass formation (c), and patient 2 had a severe jejunal stenosis due to mass formation with swelling of Kerckring folds (d).

\section{S. Nakamura', T. Matsumoto ${ }^{1}$, J. Umeno',} S. Yanai', Y. Shono' ${ }^{1}$, H. Suekane', M. Hirahashi' ${ }^{3}$, T. Yao ${ }^{3}$, M. Lida ${ }^{1}$

${ }^{1}$ Department of Medicine and Clinical Science, Graduate School of Medical Sciences, Kyushu University, Fukuoka, Japan

2 Department of Internal Medicine, Yamaguchi Red Cross Hospital, Yamaguchi, Japan

${ }^{3}$ Department of Anatomic Pathology, Graduate School of Medical Sciences, Kyushu University, Fukuoka, Japan.

\section{References}

${ }^{1}$ Nakamura S, Matsumoto T, Iida $\mathrm{M}$ et al. Primary gastrointestinal lymphoma in Japan: a clinicopathologic analysis of 455 patients with special reference to its time trends. Cancer 2003; 97: 2462 - 2473

2 Yoshino T, Miyake K, Ichimura $\mathrm{K}$ et al. Increased incidence of follicular lymphoma of the duodenum. Am J Surg Pathol 2000; 24: $688-693$

${ }^{3}$ Shia J, Teruya-Feldstein J, Pan D et al. Primary follicular lymphoma of the gastrointestinal tract: a clinical and pathologic study of 26 cases. Am J Surg Pathol 2002; 26: 216 224

${ }^{4}$ Damaj G, Verkarre V, Delmer A et al. Primary follicular lymphoma of the gastrointestinal tract: a study of 25 cases and a literature review. Ann Oncol 2003; 14: 623-629

${ }^{5}$ Matsumoto T, Esaki M, Moriyama T et al. Comparison of capsule endoscopy and enteroscopy with double-balloon method in patients with obscure bleeding and polyposis. Endoscopy 2005; 37: 827-832

\section{Corresponding author}

\section{S. Nakamura, M.D.}

Department of Medicine and Clinical Science

Graduate School of Medical Sciences

Kyushu University

Maidashi 3-1-1

Higashi-ku

Fukuoka 812-8582

Japan

Fax: $\quad+81-92-642-5273$

Email: shonaka@intmed2.med. kyushu-u.ac.jp 